\title{
Analisis Kelimpahan Bakteri Pada Ikan, Substrat, Air Serta Es Yang Digunakan Pada Pengoperasian Minitrawl Di Perairan Pamekasan
}

\author{
Fortunata Riana, Abdus Salam Junaedi*, Muhammad Zainuri \\ Program Studi Manajemen Sumberdaya Perairan, Jurusan Ilmu Kelautan dan Perikanan, Universitas \\ Trunojoyo Madura \\ Jl. Raya Telang, Telang, Kamal, Bangkalan, Jawa Timur 69162 Indonesia \\ Email: abdus.salamj@trunojoyo.ac.id
}

\section{Abstact \\ Analysis of Bacterial Abundance in Fish, Substrate, Water and Ice Used in Minitrawl Operations in Pamekasan Waters}

Fish is a source of animal protein which is generally the choice of society because it is relatively cheap and easy to obtain. Fish that are sold in dead condition are prone to quality degradiation so that bacteria can easly breed. Data on the amount of bacteria in fish related to the type of gear to another which can greatly affect the quality of the catch. Therefore, this research was conducted using a Minitrawl. The research objective was to see the amount of bacteria in fish caught using a mini fishing boat before being given and after being notified by considering the amount of bacteria in the substrate in the waters, sea water and ice cubes used by fishermen. The TPC (Total Plate Count) research method using Tryptic soy Agar (TSA) as media and pathogenic bacteria using Thiosulfate Citrate Bile Salt Sucrose Agar (TCBS) as media on fish "kardinal pita lebar" (Apogon fasciatus), sea water, substrate in the waters, and ice cubes that use for operating Minitrawl. The result of this research showed value TPC heterotrophic bacteria (TSA) which contaminated sample ITE (fish wihthout ice) 9,89 Log CFU/ml, IS (fish with ice) 9,85 Log CFU/ml, AL (sea water) 4,91 Log CFU/ml, S (substrate in the waters) 5,28 Log CFU/ml and ES (ice cubes that use for fishermen) 3,29 Log CFU/ml amount of pathogenic bacteria (TCBS) in ITE 5,27 Log CFU/ml, IS 3,24 Log CFU/ml, AL 3,45 Log CFU/ml, S 1,78 Log CFU/ml, ES 3,87 Log CFU/ml,most highest amount is in the ITE with value of TPC heterotrophic bacteria (TSA) 9,89 Log CFU/ml and pathogenic bacteria (TCBS) 5,27 Log CFU/ml.

Keywords: Total Plate Count, Apogon fasciatus, heterotrophic, pathogenic; bacteria

\begin{abstract}
Abstrak
Ikan merupakan sumber protein hewani yang umumnya menjadi pilihan masyarakat karena memiliki harga yang relatif murah dan mudah didapat. Ikan yang dijual dalam kondisi telah mati rentan terhadap penurunan kualitasnya sehingga bakteri dapat dengan mudah berkembang biak. Data tentang kelimpahan bakteri pada ikan sehubungan dengan jenis alat tangkap perlu menjadi perhatian dengan mempertimbangkan metode penangkapan yang berbeda antara satu alat tangkap dengan alat tangkap lainnya yang sangat mungkin mempengaruhi kualitas hasil tangkapannya. Oleh karena itu, penelitian dilakukan dengan menggunakan MiniTrawl. Tujuan penelitian adalah untuk mengetahui kelimpahan bakteri pada ikan yang ditangkap menggunakan MiniTrawl sebelum diberi es dan sesudah diberi es dengan mempertimbangkan kelimpahan bakteri di substrat perairan dan es batu yang digunakan nelayan. Metode penelitian TPC (Total Plate Count) menggunakan media Tryptic Soy Agar (TSA) dan bakteri patogen menggunakan media Thiosulfate Citrate Bile Salt Sucrose Agar (TCBS) pada ikan kardinal pita lebar (Apogon fasciatus), air laut, substrat perairan dan es batu yang digunakan pada pengoperasian MiniTrawl. Hasil penelitian menujukkan nilai TPC bakteri heterotrof (TSA) yang mengkontaminasi sampel ITE (ikan tanpa es) 9,89 Log CFU/ml, IS (ikan dengan es) 9,85 Log CFU/ml, AL (air laut) 4,91
\end{abstract}

*) Corresponding author

www.ejournal2.undip.ac.id/index.php/jkt
Diterima/Received : 14-07-2021, Disetujui/Accepted : 05-09-2021 DOI: https://doi.org/10.14710/jkt.v24i3.11725 
Log CFU/ml, S (substrat perairan) 5,28 Log CFU/ml dan ES (es batu yang digunakan nelayan) 3,29 Log CFU/ml. Kelimpahan bakteri patogen (TCBS) pada ITE 5,27 Log CFU/ml, IS 3,24 Log CFU/ml, AL 3,45 Log CFU/ml, S 1,78 Log CFU/ml, dan ES 3,87 Log CFU/ml. Kelimpahan tertinggi yaitu pada ITE dengan nilai TPC bakteri heterotrof (TSA) 9,89 Log CFU/ml dan bakteri patogen (TCBS) 5,27 Log $\mathrm{CFU} / \mathrm{ml}$.

Kata kunci: Total Plate Count, Apogon fasciatus, bakteri heterotrof, bakteri patogen

\section{PENDAHULUAN}

Ikan merupakan sumber protein hewani yang umumnya menjadi pilihan masyarakat karena memiliki harga yang relatif murah. Ikan yang telah mati rentan terhadap penurunan kualitasnya sehingga bakteri dapat dengan mudah berkembang biak (Dwiyitno, 2010). Penurunan kualitas bukan hanya berasal dari bakteri yang secara alami terdapat pada ikan, namun juga pada bakteri berasal dari sumber lain di antaranya adalah substrat perairan, air laut, penanganan ikan hasil tangkapan nelayan dan cara penangkapan. Pengoperasian MiniTrawl sebagai alat tangkap umumnya dioperasikan di fishing ground yang memiliki dasar perairan berpasir atau berlumpur, dan tidak terdapat karang dengan target utama ikan-ikan demersal (Aji et al., 2013).

Kualitas air tempat ikan hidup sangat berpengaruh terhadap kualitas dari ikan. Kualitas air yang baik akan menghasilkan ikan-ikan yang berkualitas dan kelangsungan hidup ikan menjadi baik. Hal tersebut sesuai dengan pernyataan Hamidah et al., 2019 kualitas air suatu perairan juga dapat menentukan mutu dari ikan yang menempati lingkungan tersebut. Kualitas suatu perairan juga berhubungan dengan substrat perairan. Bahan organik yang mengendap di substrat perairan mengakibatkan kelimpahan bakteri yang memanfaatkan bahan organik meningkat dan jumlah oksigen di perairan berkurang (Apriliana et al., 2014). Askar et al., 2018 melaporkan bahwa kelimpahan bakteri coliform pada air laut yang telah diisolasi menggunakan media LB dan BGLB. Berdasarkan laporannya, ditemukan ratarata bakteri coliform pada air laut sebanyak 9->1100 MPN/100 ml dan (Sinatryani, 2014) juga melaporkan bahwa rata-rata bakteri pada substrat perairan yang telah diisolasi menggunakan media CMC Agar berkisar antara 5,2 $\times 10^{4}-3,5 \times 10^{5} \mathrm{CFU} / \mathrm{ml}$. Junaedi et al., 2020 juga melaporkan pada ikan kurisi yang tercemar oleh bakteri heterotrof 8,59 Log CFU/g dan Vibrio sp. 5,41 Log CFU/g yang telah diisolasi menggunakan media TSA dan TCBS. Pasca panen ikan harus dilakukan penanganan. Annisah et al. (2019) menyatakan bahwa penggunaan es batu yang murah dan mudah didapatkan oleh nelayan dapat mempertahankan mutu dan kesegaran ikan hasil tangkapan. Namun, penggunaan es batu yang digunakan nelayan dinilai dapat mempertahankan mutu ikan tidak dapat lepas dari kontaminasi bakteri.

Data tentang kelimpahan bakteri pada ikan sehubungan dengan jenis alat tangkap perlu menjadi perhatian dengan mempertimbangkan metode penangkapan yang berbeda antara satu alat tangkap dengan alat tangkap lainnya yang sangat mungkin mempengaruhi kualitas hasil tangkapannya. Oleh karena itu, penelitian ini dilakukan dengan menggunakan MiniTrawl. Penelitian ini bertujuan untuk mengetahui kelimpahan bakteri pada ikan yang ditangkap menggunakan MiniTrawl sebelum diberi es dan setelah diberi es dengan mempertimbangkan kelimpahan bakteri yang terdapat di substrat perairan, perairan dan es yang digunakan nelayan.

\section{MATERI DAN METODE}

Sampel yang digunakan berupa air laut, substrat perairan, es batu yang digunakan nelayan dan daging ikan. Bahan yang digunakan pada penelitian ini antara lain $\mathrm{NaCl}$, air, spirtus, larutan alkohol $70 \%$, akuades, media TSA (Tryptic Soy Agar), media TCBS (Thiosulfate Citrate Bile Salt Sucrose).

Alat yang digunakan dalam penelitian ini antara lain: dissecting set, botol kaca 250 $\mathrm{ml}$, botol kaca $100 \mathrm{ml}$, timbangan analitik, 
GPS, autoklaf, oven, hand counter, inkubator, bunsen, nampan, korek api, kantong kresek, aluminium foil, kapas, tisu, blue tip, mikropipet, lemari pendingin, wrap plastic, alat tulis, kertas label, cool box, cawan Petri, erlenmeyer $1000 \mathrm{ml}$, gelas ukur $100 \mathrm{ml}$ dan $1000 \mathrm{ml}$, magnetic strirer, hot plate, botol spray, pengaduk, kamera, karet gelang, glove, masker, spatula, plastik berukuran $2 \mathrm{~kg}$, timbangan digital.

Pengambilan sampel dilakukan dengan mengikuti nelayan MiniTrawl yang beroperasi di perairan Pamekasan. Jenis sampel yang diambil adalah ikan Kardingl.3.1. pita lebar (Apogon fasciatus) dengan perlakuan tanpa es, ikan dengan es, substrat perairan, air laut dan es batu yang digunakan oleh nelayan. Penelitian ini dilaksanakan pada bulan November 2020 dengan menggunakan enam (6) kali jumlah towing (penarikan jaring) sebagai ulangan.

Penelitian ini menggunakan 2 jenis sterilisasi yaitu sterilisasi kering dan sterilisasi basah. Burhanuddin \& Endah, 2017 menyatakan bahwa sterilisasi kering dilakukan untuk mensterilkan beberapa peralatan gelas dengan menggunakan oven pada suhu $121^{\circ} \mathrm{C}$ selama 15 menit dan menggunakan nyala api bunsen setiap kali hendak melakukan kegiatan aseptik. Sterilisasi basah dilakukan untuk mensterilkan beberapa jenis media pertumbuhan mikroba dengan menggunakan autoklaf pada suhu $121^{\circ} \mathrm{C}$ tekanan $1 \mathrm{~atm}$ selama 15 menit (Lukas, 2006).

Sebanyak 16 g media TSA (Difco) dengan $0,9 \% \mathrm{NaCl}$, dan sebanyak $35,5 \mathrm{~g}$ media TCBS (DifCo) masing-masing media dilarutkan ke dalam $400 \mathrm{ml}$ akuades, menggunakan magnetic stirer agar proses homogen lebih cepat. Mulut botol kaca 250 $\mathrm{ml}$ ditutup dengan aluminium foil hingga rapat kemudian dilapisi wrap plastic dan selanjutnya dipanaskan menggunakan hot plate hingga mendidih. Rejeki et al. (2016) menyatakan bahwa pemanasan media pada hot plate menggunakan suhu $280^{\circ} \mathrm{C}$.

Sebanyak $18 \mathrm{~g} \mathrm{NaCl}$ larutkan dengan $2000 \mathrm{ml}$ akuades, stirer sampai merata. Sebanyak $90 \mathrm{ml}$ larutan fisiologis ( $\mathrm{NaCl} 0,9 \%$ ) menggunakan gelas ukur kedalam botol kaca $100 \mathrm{ml}$ dan ditutup dengan menggunakan aluminium foil hingga rapat dan dilakukan sterilisasi basah dengan menggunakan autoklaf pada suhu $121^{\circ} \mathrm{C}$ dan tekanan 1 atm selama 15 menit.

Sebanyak $270 \mathrm{ml}$ akuades diambil menggunakan gelas ukur dimasukkan dalam 3 buah botol kaca $100 \mathrm{ml}$ dan ditutup dengan menggunakan aluminium foil hingga rapat kemudian dilapisi wrap plastic dan dilakukan sterilisasi basah menggunakan autoklaf pada suhu $121^{\circ} \mathrm{C}$ dan tekanan $1 \mathrm{~atm}$ selama 15 menit.

Sampel ikan tanpa es yang diambil dimasukkan ke dalam plastik berukuran $2 \mathrm{~kg}$ kemudian diberi label dan dimasukkan ke dalam cool box. Sampel ikan dengan es yang diambil dimasukkan ke dalam plastik berukuran $2 \mathrm{~kg}$ kemudian diberi label dan dimasukkan ke dalam cool box. Sampel air laut diambil dari permukaan perairan di titik nelayan menangkap ikan (Nurdiana et al., 2019). Sampel air laut dimasukkan ke dalam botol sampel berukuran $300 \mathrm{ml}$ hingga rapat kemudian diberi label dan dimasukkan ke dalam cool box. Sampel substrat perairan diambil dari substrat perairan di lokasi MiniTrawl dioperasikan kemudian dimasukkan ke dalam plastik berukuran $2 \mathrm{~kg}$ kemudian diberi label dan dimasukkan ke dalam cool box. Sampel es batu yang digunakan nelayan diambil dimasukkan ke dalam plastik berukuran $2 \mathrm{~kg}$ kemudian diberi label dan dimasukkan ke dalam cool box.

\section{Isolasi bakteri heterotrof pada media TSA (Tryptic Soy Agar) dan bakteri patogen pada media TCBS (Thiosulfate Citrate Bile Salt Sucrose)}

Sampel ikan berupa daging sebanyak $10 \mathrm{~g}$, dilarutkan ke dalam $90 \mathrm{ml}$ larutan fisiologis ( $\mathrm{NaCl}$ 0,9\%). Larutan ini disebut larutan induk $10^{\circ}$. Sebanyak $10 \mathrm{ml}$ larutan induk $10^{\circ}$ diencerkan ke dalam $90 \mathrm{ml}$ larutan $\mathrm{NaCl}$ fisiologis seri pengenceran $10^{-1}$ dan pengenceran dilakukan secara bertahap sampai seri pengenceran $10^{-7}$. Isolasi pada media TCBS seri pengenceran yang digunakan adalah $10^{-2}$. Isolasi bakteri dengan menggunakan metode pour plate atau cawan taung yang digunakan untuk 
mengamati keaneka-ragaman spesies koloni yang berbeda. Menurut Dwinanti dan Tanbiyaskur (2014) metode pour plate yaitu mengambil $1 \mathrm{ml}$ larutan sampel pengenceran $10^{-2}$, kemudian dilakukan inokulasi ke dalam cawan Petri. Sebanyak 15 $\mathrm{ml}$ media TSA dan TCBS dituang ke dalam cawan Petri dan dihomogenkan secara perlahan-lahan dengan menggerakkan cawan Petri hingga membentuk angka delapan. Setelah media TSA dan TCBS memadat, dilakukan inkubasi selama 24 jam pada suhu $35^{\circ} \mathrm{C}$ (Lestari et al. 2016). Selanjutnya dilakukan pengamatan karakteristik koloni bakteri dari hasil isolasi bakteri. Menurut Wahjuningrum et al. (2013) karakteristik koloni bakteri dapat diamati dengan menggunakan karakter berupa bentuk koloni, ukuran koloni, warna koloni, elevasi koloni, dan tepi koloni.

Sampel ikan yang telah beku di diamkan pada suhu ruang beberapa menit hingga es mencair. Setelah ikan tidak lagi beku diambil dagingnya sebanyak $10 \mathrm{~g}$, kemudian dilakukan pengenceran ke dalam $90 \mathrm{ml}$ larutan fisiologis ( $\mathrm{NaCl} 0,9 \%$ ). Larutan ini disebut larutan induk $10^{\circ}$. Sebanyak $10 \mathrm{ml}$ pada $10^{\circ}$ diencerkan ke dalam $90 \mathrm{ml}$ larutan $\mathrm{NaCl}$ fisiologis seri pengenceran $10^{-1}$ dan pengenceran dilakukan secara bertahap sampai larutan sampel seri pengenceran $10^{-7}$. Isolasi pada media TCBS menggunakan seri pengenceran $10^{-2}$. Isolasi bakteri dan pengamatan karakteristik koloni bakteri pada sampel ikan dengan es dilakukan dengan metode seperti sebelumnya.

Sebanyak $10 \mathrm{ml}$ sampel air laut dilakukan pengenceran dengan menggunakan botol kaca $100 \mathrm{ml}$ berisi larutan fisiologis $(\mathrm{NaCl}$ 0,9\%) dilarutkan ke dalam $90 \mathrm{ml}$. Larutan ini disebut sebagai sebagai larutan induk $10^{\circ}$. Sebanyak $10 \mathrm{ml}$ larutan induk $10^{\circ}$ diencerkan ke dalam $90 \mathrm{ml}$ larutan fisiologis ( $\mathrm{NaCl} \quad 0,9 \%)$ seri pengenceran $10^{-1}$ dan dilakukan pengenceran secara bertahap sampai pada larutan fisiologis ( $\mathrm{NaCl} 0,9 \%)$ seri pengenceran $10^{-2}$. Isolasi pada media TCBS menggunakan seri pengenceran $10^{-1}$. Isolasi dan pengamatan karakteristik koloni bakteri pada sampel air laut dilakukan dengan metode seperti sebelumnya.
Sampel substrat perairan sebanyak $10 \mathrm{~g}$ dilakukan pengenceran ke dalam $90 \mathrm{ml}$ larutan $\mathrm{NaCl}$ fisiologis sebagai larutan induk $10^{\circ}$. Sebanyak $10 \mathrm{ml}$ pada larutan $10^{\circ}$ diencerkan ke dalam $90 \mathrm{ml}$ larutan $\mathrm{NaCl}$ fisiologis (larutan sampel seri pengenceran $\left.10^{-1}\right)$. Pengenceran dilakukan secara bertahap sampai pada larutan sampel seri pengenceran $10^{-3}$. Isolasi pada media TCBS menggunakan seri pengenceran $10^{-1}$. Isolasi bakteri dan pengamatan karakteristik koloni bakteri pada sampel substrat perairan dilakukan dengan metode yang sama seperti pada kegiatan yang telah dilakukan.

Sampel es batu yang telah cair dilakukan pengenceran dengan menggunakan botol kaca $100 \mathrm{ml}$ Sampel es batu $10 \mathrm{ml}$ dilarutkan ke dalam $90 \mathrm{ml}$ akuades steril. Sebanyak $10 \mathrm{ml}$ pada larutan induk $10^{\circ}$ diencerkan ke dalam $90 \mathrm{ml}$ akuades steril seri pengenceran $10^{-1}$ dan pengenceran dilakukan secara bertahap sampai pada larutan sampel seri pengenceran $10^{-2}$. Isolasi pada media TCBS menggunakan seri pengenceran $10^{-1}$. Isolasi dan pengamatan karakteristik koloni bakteri pada es batu dilakukan seperti kegiatan yang telah dilakukan.

Penghitungan nilai TPC bakteri dilakukan dengan menghitung koloni bakteri secara keseluruhan pada sampel air laut, substrat perairan, es batu yang digunakan nelayan dan daging ikan. Menurut Ingr, 2010 TPC merupakan metode yang dilakukan untuk menghitung kelimpahan mikroba.

Pengamatan karakteristik morfologi koloni bakteri dilakukan secara makroskopis hasil isolasi pada sampel air laut, substrat perairan, es batu yang digunakan nelayan dan daging ikan dari media TSA dan TCBS pada prosedur yang telah dilakukan. Karakteristik yang diamati yaitu warna, bentuk, ukuran, tepi, dan elevasi (Wahjuningrum et al., 2013). Pada pengamatan morfologi koloni bakteri dilakukan secara makroskopis menggunakan kasat mata.

Hasil analisis perhitungan nilai TPC dan pengamatan karakteristik koloni bakteri dari sampel ikan tanpa es, ikan dengan es, air laut, substrat peraira, dan es batu yang 
digunakan nelayan dianalisis secara deskriptif berdasarkan visualisasi.

\section{HASIL DAN PEMBAHASAN}

Ikan kardinal pita lebar (A. fasciatus) perlakuan tanpa es dan dengan es memiliki ukuran hampir sama yaitu rata-rata panjang tubuh $9,5 \mathrm{~cm}$ sedangkan rata-rata berat tubuh 13,5 g. Ukuran panjang ikan A. fasciatus menurut Goren et al., 2009 adalah $10 \mathrm{~cm}$. Gökoğlu et al., 2012 melaporkan berat total minimum dan maksimum ikan $A$. fasciatus yang di tangkap di Gulf Antalya, Turkey adalah 1,49 dan 6,55 g.

Hasil analisis nilai TPC pada ITE (ikan tanpa es) dan IS (ikan dengan es) memperoleh hasil yang telah disajikan pada Gambar 1. Berdasarkan Gambar 1 dapat diketahui bahwa kegiatan isolasi bakteri heterotrof dan patogen dari sampel ikan kardinal pita lebar (A. fasciatus) tanpa es dan dengan es pada masing-masing jenis menunjukkan nilai TPC (Total Plate Count) yang berbeda. Perbedaan nilai TPC pada media TSA dan TCBS ini dimungkinkan oleh perlakuan yang diberikan pasca panen. Ikan yang dengan es nilai TPC nya lebih rendah, dikarenakan pemberian es dapat menekan pertumbuhan bakteri. Hal tersebut sesuai dengan pernyataan syafitri et al., 2016 menyatakan bahwa, penanganan ikan dengan pemberian es dapat mempertahankan mutu dan dapat menekan pertumbuhan bakteri. Nilai TPC bakteri hetotrof ikan kardinal pita lebar (A. fasciatus) ITE dan IS pada media TSA adalah 9,89 Log $\mathrm{CFU} / \mathrm{g}$ dan 9,85 Log CFU/g (Gambar 1). Badan Standarisasi Nasional (SNI-01-27292006) menyatakan bahwa batas maksimum cemaran pada ikan segar, yaitu $5 \mathrm{CFU} / \mathrm{g}$ atau setara dengan 5,69 log CFU/g. Menurut Ingr, 2010 menyatakan bahwa standar maksimum kontaminasi bakteri pada ikan yaitu $1 \times 10^{6} \mathrm{CFU} / \mathrm{g}$ atau setara dengan $6 \mathrm{log}$ CFU/g.

Nilai TPC bakteri patogen ikan kardinal pita lebar (A. fasciatus) ITE 5,27 Log CFU/g dan IS 3,24 Log CFU/g (Gambar 1). Standar kontaminasi bakteri Vibrio sp. pada ikan segar berdasarkan (IAMS, 1962) sebesar 0/g. CSN 569609 (2008) juga melaporkan maksimum kontaminasi bakteri Vibrio sp. pada ikan segar adalah 0/25g.

Hasil penelitian ini menunjukkan nilai TPC bakteri heterotrof dan bakteri patogen pada sampel ITE dan IS melebihi batas maksimum kontaminasi bakteri yang dapat menyebabkan penurunan mutu ikan. Menurut Apriani et al., 2017 semakin tinggi angka cemaran bakteri pada ikan menyebabkan kualitas ikan semakin menurun. Tingginya nilai TPC IS pada media TSA dan TCBS dimungkinkan oleh kualitas es yang digunakan selama penanganan (ES) hasil tangkapan di kapal. Selain itu, nilai TPC bakteri heterotrof yang tinggi pada ikan dapat juga berkaitan dengan AL (air laut) dan $S$ (substrat perairan). Air laut mengandung nutrien yang dimanfaatkan oleh ikan sebagai bahan makanan kemudian sisa makanan dan kotoran ikan akan mengendap di substrat perairan menjadi bahan organik. Bahan organik yang tinggi akan memiliki senyawa karbon organik sebagai sumber makanan bakteri (Askar et al., 2018).

Kontaminasi bakteri Vibrio sp. sering dikaitkan dengan makanan laut sebagai kontaminan alami. bakteri Vibrio sp. dapat menyebabkan penyakit infeksi pada manusia (Wagey et al., 2013). Menurut Alaboudi et al., 2016 Vibrio sp. tersebar di lingkungan laut dan menyebabkan penyakit gastroenteritis pada manusia. Autlet et al., 2007 juga melaporkan kontaminasi bakteri Vibrio choleraeyang dapat menyebabkan penyakit diare kolera. Vibrio cholera banyak ditemukan pada permukaan air.

Bakteri patogen Vibrio sp. yang menginfeksi ikan dapat menghambat pertumbuhan ikan dan apabila dikonsumsi oleh manusia dapat menyebabkan penyakit gastroenteritis (Sutiknowati, 2013). Hasil penelitian ini menunjukkan nilai TPC bakteri patogen pada ikan tinggi. Hal tersebut sesuai dengan pernyataan Sutiknowati, 2013 bakteri patogen pada biota laut dapat menjadi indikator biota laut terinfeksi melalui air laut dan substrat perairan.

Analisis terhadap kelimpahan bakteri heterotrof dan patogen pada AL 
memperoleh hasil nilai TPC seperti yang telah disajikan pada (Gambar 1). Nilai TPC bakteri heterotrof AL pada media TSA adalah 4,91 Log CFU/g (Gambar 1). Menurut Askar et al., 2018 kelimpahan bakteri pada air laut berkisar antara 9->1100 MPN/100 ml. Kementrian Lingkungan Hidup Nomor 51 tahun 2004 juga menyatakan standar baku mutu kelimpahan bakteri pada air laut sebesar 1000 MPN/100 ml.

Nilai TPC bakteri patogen AL pada media TCBS adalah 3,45 Log CFU/g (Gambar 1). Menurut Ganesh et al. (2010), quorum sensing bakteri Vibrio sp. di perairan adalah 103. Menurut Pepenfort et al., 2016 quorum sensing merupakan jumlah kelimpahan minimal bakteri Vibrio sp. untuk mengekspresikan sifat patogennya.

Nilai TPC pada AL menunjukkan nilai TPC pada media TSA lebih tinggi, hal tersebut diduga karena tingginya kandungan organik yang ada pada air laut sehingga menyebabkan tingginya nilai TPC pada bakteri heterotrof. Hal tersebut sesuai dengan pernyataan Askar et al., 2018 menyatakan bahwa, tingginya kandungan organik pada air laut menjadi penyebab melimpahnya bakteri pada lingkungan tersebut. Lou et al., 2010 juga menyatakan bahwa bahan organik yang berada dilingkungan bakteri heterotrof hidup dimanfaatkan sebagai sumber nutrisi.

Hasil analisis terhadap kelimpahan bakteri heterotrof pada $S$ memperoleh hasilnilai TPC seperti yang telah disajikan pada (Gambar 1). Nilai TPC bakteri heterotrof $S$ adalah 5,28 Log CFU/g (Gambar 1). Sari dan Agus, (2014) menyatakan bahwa kelimpahan bakteri heterotrof pada substrat perairan berkisar antara $0,60 \times 10^{-5}$ $1,35 \times 10^{-5} \mathrm{CFU} / \mathrm{g}$.

Nilai TPC bakteri patogen S adalah 1,78 Log CFU/g (Gambar 1). Askar et al., 2018 melaporkan kelimpahan bakteri Vibrio sp. pada substrat perairan berkisar antara 7,3-7,9 Log CFU/g. Lailatussyifa et al., 2020 juga melaporkan, kelimpahan bakteri Vibrio sp. pada sedimen berkisar antara 4,0 X 104 - 7,8 X $10^{4} \mathrm{Log}$ CFU/g.

Nilai TPC pada $S$ menunjukkan pada media TSA lebih tinggi. Melimpahnya bakteri heterotrof pada substrat perairan dapat disebabkan oleh bakteri dan bahan-bahan organik yang berada diperairan mengendap dilapisan substrat perairan. Menurut Askar et al., 2018 tingginya bakteri heterotrof pada $\mathrm{S}$ dibandingkan dengan AL karena tidak terjadi resuspensi substrat perairan. Melimpahnya bakteri heterotrof pada substrat perairan didukung oleh keadaan substrat perairan

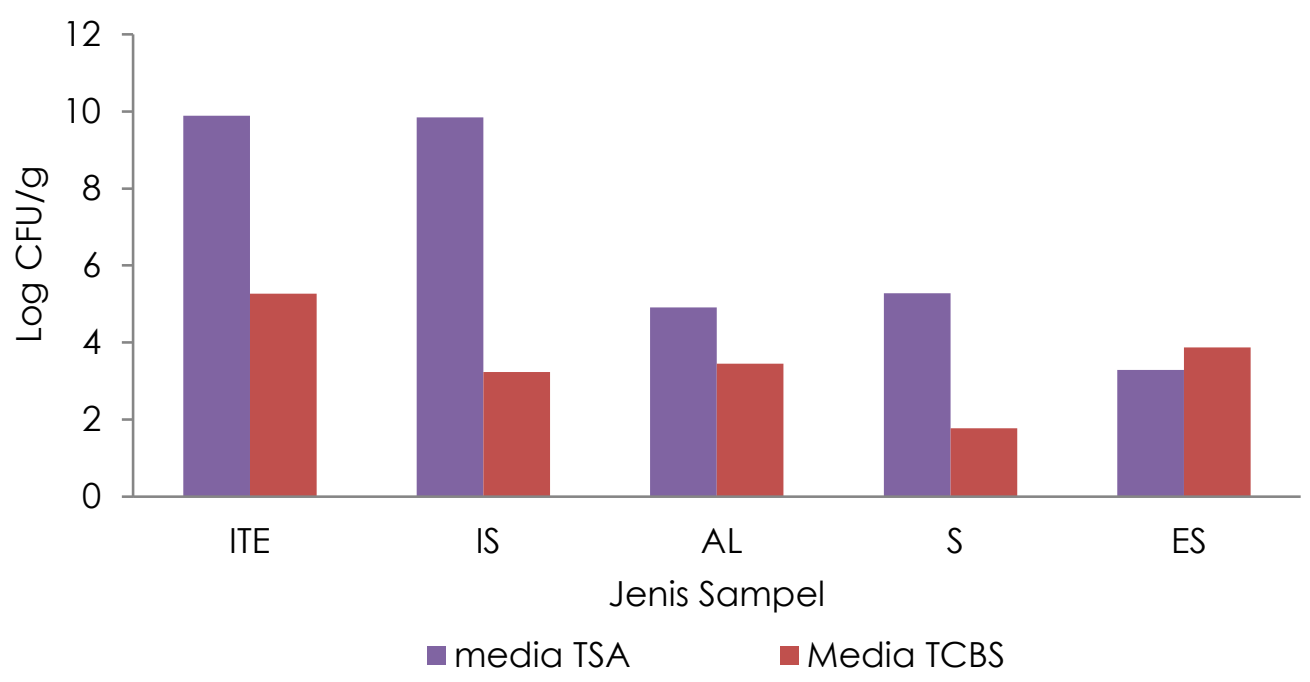

Gambar 1. Nilai TPC (Total Plate Count) dari bakteri patogen dan bakteri heterotrof (Log CFU/g) yang berhasil dihitung pada media TSA dan TCBS.

Keterangan: ITE= ikan tanpa es, IS = ikan dengan es, $A L=$ air laut, $S=$ substrat perairan, $\mathrm{ES}=$ es yang digunakan nelayan. 
yang berlumpur, memungkinkan akumulasi bahan organik pada substrat perairan. Bahan organik yang tinggi akan memiliki senyawa karbon organik sebagai sumber makanan bakteri (Askar et al., 2018).

Hasil analisis terhadap kelimpahan bakteri heterotrof pada ES memperoleh hasil nilai TPC seperti yang telah disajikan pada (Gambar 1). Nilai TPC bakteri heterotrof es batu yang digunakan nelayan adalah 3,29 Log CFU/g (Gambar 1). Berdasarkan SNI 013839-1995 kualitas es batu yang digunakan nelayan secara mikrobiologis tidak terpenuhi hanya dengan memasak bahan air yang dimasak, tetapi juga memperhatikan faktor pengolahan, pengemasan dan pendistribusian.

Nilai TPC bakteri patogen ES adalah 3,87 Log CFU/g (Gambar 1). Rohman \& Tutiek, 2018 melaporkan bahwa rata-rata kelimpahan bakteri patogen pada es batu balok berkisar 0,244 x $104 \mathrm{CFU} / \mathrm{ml}$. Liliana et al., 2016 melaporkan bahwa bakteri patogen pada es batu balok $6,23 \times 10^{3} \mathrm{CFU} / \mathrm{ml}$ Pengolahan dan penangganan es batu yang tidak terjaga ke higienisannya dapat menyebabkan melimpahnya bakteri.

\section{Keragaman Spesies Koloni Bakteri}

Hasil penelitian pengamatan karakteristik menunjukkan jenis koloni bakteri heterotrof memiliki karakter morfologi yang berbeda-beda. Karakter bentuk koloni ITE dan IS (Tabel 1), menunjukkan jenis koloni bakteri heterotrof yang berhasil diisolasi dari sampel ITE dan IS memiliki karakteristik koloni yang sama yaitu warna koloni krem; bentuk melingkar, tidak beraturan; tepian koloni bakteri memiliki kesamaan pada rata, tidak beraturan, berombak, yang berbeda pada IS memiliki tepian seperti benang-benang tetapi tidak ada pada ITE; elevasi memiliki kesamaan pada sedikit cembung dan cembung namun datar pada is tidak terdapat pada ITE; Ukuran sedang pada ITE terdapat juga pada IS meskipun pada IS terdapat juga kecil dan besar.

Tabel 1. Keragaman spesies koloni bakteri heterotrof pada media TSA.

\begin{tabular}{|c|c|c|c|c|c|}
\hline \multirow{2}{*}{$\begin{array}{l}\text { Pengamatan } \\
\text { Makroskopik }\end{array}$} & \multicolumn{5}{|c|}{ Koloni Bakteri Media TSA } \\
\hline & ITE & IS & $\mathrm{AL}$ & $S$ & ES \\
\hline Warna & Krem & Krem & Krem & Krem & Krem \\
\hline \multirow{3}{*}{ Bentuk } & $\begin{array}{l}\text { Melingkar, } \\
\text { Tidak } \\
\text { beraturan }\end{array}$ & $\begin{array}{l}\text { Melingkar, } \\
\text { Tidak } \\
\text { beraturan }\end{array}$ & $\begin{array}{l}\text { Melingkar, } \\
\text { Seperti } \\
\text { benang- } \\
\text { benang } \\
\text { radler }\end{array}$ & $\begin{array}{c}\text { Melingkar, } \\
\text { Berkerut }\end{array}$ & \multirow{3}{*}{ Melingkar } \\
\hline & & $\begin{array}{c}\text { Tidak } \\
\text { Beraturan, Ra }\end{array}$ & & & \\
\hline & $\begin{array}{l}\text { Rata, } \\
\text { Berombak, } \\
\text { Tidak }\end{array}$ & $\begin{array}{c}\text { ta, } \\
\text { Berombak, } \\
\text { Seperti } \\
\text { benang- }\end{array}$ & $\begin{array}{l}\text { Rata, } \\
\text { Berlekuk, } \\
\text { Seperti } \\
\text { benang- }\end{array}$ & \multirow{2}{*}{$\begin{array}{c}\text { Rata, Seprti } \\
\text { benang- } \\
\text { benang }\end{array}$} & \\
\hline Tepian & beraturan & $\begin{array}{c}\text { benang } \\
\text { Sedikit }\end{array}$ & benang & & Rata \\
\hline Elevasi & $\begin{array}{l}\text { Sedikit } \\
\text { cembung, } \\
\text { cembung }\end{array}$ & $\begin{array}{c}\text { cembung, } \\
\text { cembung, } \\
\text { datar } \\
\text { Kecil, }\end{array}$ & $\begin{array}{l}\text { Cembung, } \\
\text { Datar, Sedikit } \\
\text { cembung }\end{array}$ & $\begin{array}{l}\text { Cembung, } \\
\text { Berlipat, } \\
\text { Datar }\end{array}$ & Datar \\
\hline Ukuran & Sedang & $\begin{array}{l}\text { Sedang, } \\
\text { Besar }\end{array}$ & Sedang, Kecil & $\begin{array}{c}\text { Kecil, } \\
\text { Sedang }\end{array}$ & Kecil \\
\hline
\end{tabular}

Keterangan: ITE= ikan tanpa es, IS = ikan dengan es, $\mathrm{AL}=$ air laut, $\mathrm{S}=$ substrat perairan, $\mathrm{ES}=\mathrm{es}$ yang digunakan nelayan. 
Tabel 2. Keragaman spesies koloni bakteri patogen pada media TCBS

\begin{tabular}{|c|c|c|c|c|c|}
\hline \multirow{2}{*}{$\begin{array}{l}\text { Pengamatan } \\
\text { Makroskopik }\end{array}$} & \multicolumn{5}{|c|}{ Koloni Bakteri Media TSA } \\
\hline & ITE & IS & $\mathrm{AL}$ & $S$ & ES \\
\hline Warna & $\begin{array}{c}\text { Kuning, Hijau } \\
\text { Melingkar, }\end{array}$ & Kuning, Hijau & Kuning, Hijau & Kuning & Kuning \\
\hline & $\begin{array}{l}\text { Berlekuk, } \\
\text { Tidak }\end{array}$ & Melingkar, & $\begin{array}{l}\text { Melingkar, } \\
\text { Tidak }\end{array}$ & $\begin{array}{l}\text { Melingkar, } \\
\text { Tidak }\end{array}$ & \\
\hline Bentuk & $\begin{array}{c}\text { beraturan } \\
\text { Rata, }\end{array}$ & Rata & beraturan & beraturan & Melingkar \\
\hline Tepian & $\begin{array}{c}\text { Berlekuk, } \\
\text { Tidak } \\
\text { beraturan } \\
\text { Datar, }\end{array}$ & $\begin{array}{l}\text { Rata, Tidak } \\
\text { beraturan }\end{array}$ & $\begin{array}{l}\text { Rata, } \\
\text { Berombak }\end{array}$ & $\begin{array}{l}\text { Rata, } \\
\text { Berombak }\end{array}$ & Rata \\
\hline Elevasi & $\begin{array}{l}\text { Cembung, } \\
\text { Sedikit } \\
\text { cembung }\end{array}$ & $\begin{array}{l}\text { Cembung, } \\
\text { Sedikit } \\
\text { cembung } \\
\text { Sedang, }\end{array}$ & $\begin{array}{c}\text { Cembung, } \\
\text { Datar, Rata } \\
\text { Kecil, Sedang, }\end{array}$ & $\begin{array}{l}\text { Cembung, } \\
\text { Datar } \\
\text { Kecil, }\end{array}$ & Datar \\
\hline Ukuran & Kecil & Besar & Besar & Sedang & Kecil \\
\hline
\end{tabular}

Keterangan: $\mathrm{ITE}=\mathrm{ikan}$ tanpa es, IS = ikan dengan es, $\mathrm{AL}=$ air laut, $\mathrm{S}=$ substrat perairan, $\mathrm{ES}=\mathrm{es}$ yang digunakan nelayan.

Menurut Wahjuningrum et al., 2013 morfologi koloni pada media TSA berwarna krem, elevasi cembung dan tepiannya halus. Junaedi et al., 2020 melaporkan bahwa, pada koloni bakteri heterotrof yang diisolasi dari daging ikan memiliki karakteristik morfologi yang beragam.

Berbeda dengan jenis bakteri patogen dari sampel ITE dan IS pada media TCBS (Tabel 2). ITE dan IS memiliki karakteristik warna koloni yang sama yaitu kuning dan hijau; bentuk koloni melingkar, yang berbeda pada ITE memiliki bentuk berlekuk, tidak beraturan dan IS memiliki bentuk rata. Tepian koloni bakteri rata, tidak beraturan tetapi pada ITE juga memiliki tepian berlekuk. Elevasi memiliki kesamaan pada cembung dan sedikit cembung namun datar pada ITE tidak terdapat pada IS; Ukuran ITE dan IS memiliki perbedaan yaitu pada ITE kecil sedangkan IS sedang dan besar. Menurut Ihsan \& Retnaningrum, 2017 koloni bakteri Vibrio sp. pada media TCBS memiliki morfologi koloni yaitu warna kuning, hijau, bentuk koloni melingkar, tepian rata dan elevasi cembung dan cekung. Menurut Hidayat, 2013 warna koloni kuning pada media TCBS terjadi ketika bakteri memfermentasikan sukrosa.
Koloni bakteri heterotrof pada AL, S, dan ES juga memiliki kesamaan warna yaitu krem; bentuk melingkar namun pada AL terdapat seperti benang-benang radler sedangkan S berkerut; tepian rata, tetapi AL dan $S$ memiliki tepian yang sama yaitu seperti benang-benang namun yang membedakan AL berlekuk; elevasi datar tetapi AL dan S juga memiliki elevasi cembung namun yang berbeda AL terdapat sedikit cembung; ukuran kecil tetapi AL dan S memiliki ukuran sedang. Cappucino dan Suherman, 2002 menyatakan keanekaragaman morfologi koloni bakteri dapat mengindikasikan koloni bakteri tersebut berasal dari spesies yang berbeda. Rinawati et al., 2015 juga menyatakan bahwa ukuran koloni bakteri dipengaruhi oleh medium pertumbuhan.

Jenis bakteri patogen dari sampel AL, S, dan ES memiliki warna yang sama yaitu kuning namun pada AL memiliki warna lain yaitu hijau; bentuk melingkar, tidak beraturan tetapi pada ES hanya memiliki bentuk melingkar; tepian rata, berombak tetapi pada ES hanya memiliki tepian rata; elevasi sama memiliki kesamaan datar, cembung tetapi AL, S juga memiliki elevasi yang sama cembung namun AL juga memiliki elevasi rata; ukuran kecil yang membedakan pada AL dan S memiliki ukuran sedang dan AL juga 
memiliki ukuran besar. Hidayat et al., 2006 menyatakan bahwa bentuk koloni bakteri dipengaruhi oleh umur dan syarat pertumbuhan tertentu. Pertumbuhan koloni bakteri dipengaruhi oleh aktivitas pertumbuhan bakteri, bakteri yang tidak mampu bersaing untuk memperoleh nutrisi atau makanan akan menyebabkan koloni bakteri tersebut berukuran kecil (Rinawati et al., 2015).

Mempertimbangkan hasil yang diperoleh melalui pengamatan mikroskopis semua perlakuan yang diisolasi baik pada media TSA maupun TCBS yang cenderung banyak terdapat persamaan pada factor warna, bentuk, tepian, elevasi dan ukuran, maka dapat diduga kelimpahan bakteri pada perlakuan ikan tanpa es (ITE) terkait dengan kondisi air laut (AL) dan substrat perairan (S), sedangkan pada perlakuan ikan yang diberi es (IS) terkait dengan kondisi air laut (AL), substrat perairan (S) dan es (ES) yang digunakan sebagai bahan pengawet hasil tangkapan nelayan MiniTrawl.

\section{KESIMPULAN}

Kelimpahan bakteri heterotrof dan patogen yang mengkontaminasi sampel ITE (ikan tanpa es), IS (ikan es), AL (air laut), S (substrat perairan) dan ES (es batu yang digunakan nelayan) MiniTrawl diperairan Pamekasan yang memiliki kelimpahan tertinggi yaitu pada ikan tanpa es dengan kelimpahan bakteri heterotrof 9,89 Log $\mathrm{CFU} / \mathrm{ml}$ dan bakteri patogen 5,27 Log $\mathrm{CFU} / \mathrm{ml}$

\section{UCAPAN TERIMA KASIH}

Terima kasih diucapkan kepada dosen pembimbing skripsi dan semua pihak yang telah membantu kelancaran penelitian dan penulisan artikel ini.

\section{DAFTAR PUSTAKA}

Aji, I.N., Bambang, A.W. \& Asriyanto. 2013. Analisis Faktor Produksi Hasil Tangkapan Alat Tangkap Cantrang Di Pangkalan Pendaran Ikan Bulu Kabupaten Tuban. Journal of Fisheries Resources Utilization Managemen and Technology. 2(4):50-58
Alaboudi, A.R., Ababneh, M., Osaili, T.M. \& Shloul, K.A. 2016. Detection, identifivation, and prevalence of pathogenic Vibrio parahaemolyticus in fish and coastal environment in Jordan. Journal of Food Science. 81(1):130-134 doi: $10.1111 / 1750-3841.13151$

Annisah, U., Giri, R.B. \& Farida, A., 2019. Pengaruh Penyimpanan Terhadap Profil Formaldehida Alami Dan Kemunduran Mutu Pada Ikan Beloso (Saurida tumbil). Jurnal Pengolahan Hasil Perikanan Indonesia. 22(3):535-547. doi: 10.17844/jphpi.v22i3.29123

Apriani, R., Reza, F. \& Razali, R. 2017. Jumlah Cemaran Mikroba Dan Nilai Organoleptik Ikan Tongkol (Euthynnus affinis). Jurnal Ilmiah Mahasiswa Veteriner. 1 (3):598-603

Apriliana, R., Siti, R., Pujiono, W.P. 2014. Keanekaragaman Jenis Bakteri Perairan Dasar Berdasarkan Tipe Tutupan Permukaan Perairan Di Rawa Pening. Diponegoro Journal Of Maquares. 3(2), 119-128

Askar, A.T., Mochamad, U.K.A.,Yuli, A., \& Lintang, P.Y. 2018. Kelimpahan Bakteri Coliform Pada Air Laut, Sedimen dan Foraminifera Jenis Calcarina Di Ekosistem Terumbu Karang Pulau Pramuka, Kepulauan Seribu, DKI Jakarta. Jurnal Akuatika Indonesia. 3, 36-41. doi: 10.24198/jaki.v3i1.23391

Aulet, O., Silva, C., Fraga, S.G., Pichel, M., Cangemi, R., Gaudioso, C., Porcel, N., Jure, M.A., Castillo, M.C.D. \& Binsztein, N. 2007. Detection of viable nonculturable Vibrio cholerae $\mathrm{O} 1$ through cultures and immuno-fluorescenee in Tucuman rivers, Argentina. Revista da sociedade brasileira de Medicina Tropical, 40: 385390. doi: 10.1590/\$0037-8682200 7000400002

Badan Pengawas Obat dan Makanan. 2009. Peraturan Kepala Badan Pengawas Obat dan Makanan RI Nomor. HK. 00.06.1.52.4011. Tentang Penetapan Batas Maksimum Cemaran Mikroba dan Kimia Dalam Makanan, Jakarta

Badan Standarisasi Nasional [BSN]. 2009. Batas Maksimum Cemaran Mikroba dalam Pangan. SNI 7388:2009. Jakarta: Badan Standarisasi Nasional 
Burhanuddin, I. \& Endah, R. 2017. Isolasi Dan Identifikasi Bakteri Vibrio sp. Pada Kerang Kapah (Meretrix meretrix) Di Kabupaten Trenggalek. Jurnal Harpodon Borneo. 10(1):23-27

Cappucino, J.G. \& Sherman, N. 2002. Microbiology A Laboratory Manual, 6th ed. Menlo Park: The Benjamin /Cummings Publishing Company, Inc: xvi + $491 \mathrm{hlm}$.: Benjamin Cummings

CSN 569609. 2008. Guides to good hygiene and manufacturing practice microbiological criteria for foods principles for the establishment and application

Dwinanti, S.H. \& Tanbiyaskur. 2014. Rekayasa Media Padat Untuk Bakteri Akuatik. Jurnal Akuakultur Indonesia. 13(2):163166. doi: 10.19027/jai.13.163-166

Dwiyatno. 2010. Identifikasi bakteri patogen pada produk perikanan dengan teknik molekuler. Jurnal Squalen. 5(2):67-78

Ganesh, E.A., Das, S., Chandrasekar, K., Arun, G. \& Balamurugan, S., 2010. Monitoring of Total Heterotrophic Bacteria and Vibrio spp. in a Aquaculture pond. Current Research Journal of Biological Sciences. 2(1), 48-52

Gökoğlu, M., Özvarol, Y. \& Balci, B.A., 2012. Westward extension of the indo-pacific cardinal fish Apogon fasciatus (White, 1790) along the Turkish Coast. Journal compilation. 1(3):225-227. doi: 10.3391/bir.2012.1.3.09

Goren, M., Galil, B.S., Diamant, A., Gayer, K. \& Stern, N. 2009. First record of the IndoPacific cardinal fish Apogon fasciatus (White, 1790) in the Mediterranean Sea. Aquatic Invasions 4(2):409-411. doi: 10.3391/ai.2009.4.2.21

Suhartini, S., Padaga, C.M. \& Hidayat, N. 2006. Mikrobiologi Industri. Penerbit ANDI, Yogyakarta

IAMS (International Association of Microbiological Societies). 1962. (www. Microbialstandard.com).

Ihsan, B., Retnaningrum, E. 2017. Isolasi dan identifikasi bakteri Vibrio sp. pada kerang kapah (Meretix meretix) di Kabupaten Trenggalek. Jurnal Harpodon Borneo. 10(1):23-27

Ingr, I. 2010. Fish Quality and Processing. (Jakosta zpracovani ryb). 2nd ed. Brno: Mendelova univerzita $\vee$ Brne, $102 \mathrm{p}$.
Junaedi, A.S., Riana, F., Sari, H.C.P., Witria, W. \& Zainuri, M. 2020. Kualitas Daging Ikan Kurisi (Nemipterus japonicus) Hasil Tangkapan Nelayan Di Pelabuhan Perikanan Branta, Pamekasan. Jurnal Pengolahan Hasil Perikanan Indonesia. 23(2):304-321. doi: 10.17844/jphpi.v23i2.31169

Keputusan Menteri Lingkungan Hidup Bidang Kebijakan dan Kelembagaan Lingkungan Hidup. 2004. Standar Baku Mutu Air Laut Nomor 51 Tahun 2004. Jakarta: Kementerian Lingkungan Hidup Rl.

Lestari, N.W., Budiharjo, G. \& Pangastuti, A. 2016. Bakteri Heterotrof Aerobik Asal Saluran Pencernaan Ikan Sidat (Anguilla bicolor bicolor) Dan Potensinya sebagai Probiotik. Bioteknologi. 13(1):9-17. doi: 10.1305 7/bio tek/c130102

Liliana, D.P., Maria, S., Dewi, R. \& Astuti I. 2016. Perbandingan Jumlah Koloni Bakteri Kontaminan Pada Es Balok dan Es Kristal di Pabrik Es Batu dan Penjual Minuman Sekitar Unisba. Universitas Islam Bandung. 273-278

Lukas, S. 2006. Formulasi Steril. Yogyakarta : Penerbit Andi hal. 9-14; 82-84; 86-99

Mile, L. 2013. Analisis TPC dan Total Bakteri Psikrofilik pada Ikan Layang (Decapterus macrosoma) Selama Penyimpanan Suhu Rendah. Jurnal Ilmiah Perikanan dan Kelautan. 1(2): 103-106

Notowinarto \& Fenny, A. 2015. Populasi Bakteri Heterotrof Di Perairan Bulang Batam. Jurnal Pendidikan Biologi Indonesia. 1 (3):334-342

Nurdiana, F., Pande, G.S.J. \& Endang, W.S. 2019. Kelimpahan Bakteri Coliform Pada Musim Kemarau di Perairan Laut Celukanbawang, Provinsi Bali. Jurnal Current Trends in Aquatic Science. 2(1):101-107

Rejeki, S., Triyanto \& Murwantoko. 2016. Isolasi dan Identifikasi Aeromonas spp. Dari Lele Dumbo (Clarias sp.) Sakit Di Kabupaten Ngawi. Jurnal Perikanan Universitas Gadjah Mada. 18(2):55-60. doi: $10.22146 / \mathrm{jfs} .26917$

Rinawati, L.P, Arsana, I.N. \& Juliasih, N.K.A. 2015. Pengaruh konsentrasi natrium chloride pada media alkaline peptone water terhadap pertumbuhan bakteri Vibrio cholera. Meditory. 3(1):1-9 
Sari, E.P \& Agus, J.E. 2014. Dinamika Populasi Bakteri Heterotrof Dan Autotrof Pada Pengolahan Sludge Produced Water Hasil Eksplorasi Minyak Dan Gas Bumi Dengan Metode Aerated Static Pile Dan Degradasi Anaerobik. Jurnal Teknik Lingkungan. 1(20):68-77. doi: 10.5614/jtl. 2014.20.1.8

Sethi, L. 2014. Pathogenicity, genetic aspects and characterization of Virio species Isolated from Marine Environment. Thesis. Department of Life Science National Institue of Technology Rourkela, Odisha.

[SNI] Standar Nasional Indonesia. Es Batu. Jakarta: Badan Standarisasi Nasional 1995. SNI 01-3839-1995

Supriharyono. 2009. Konservasi Ekosistem Sumberdaya Hayati, Di Wilayah Pesisir dan Laut Tropis. Pustaka Pelajar, Jogjakarta

Sutiknowati, L.I. 2013. Mikroba Parameter
Kualitas Perairan P. Pari Untuk Upaya Pembesaran Biota Budidaya. Jurnal IImu dan Teknologi Kelautan Tropis. 5 (1):204218. doi: 10.29244/jitkt.v5il.7769

Wagey, I.N.D., Frans, G.I. \& Joyce, C.V.P. 2013. Tingkat Kontaminasi Vibrio cholerae Resisten Merkuri Diisolasi Dari Ikan Kuwe (Caranax sexfasciatus). Jurnal Media Teknologi Hasil Perikanan. 1 (1):2125 doi : 10.35800/ mthp.1.1.2013.4142

Wahjuningrum, D., Retno, A. \& Mia, S. 2013. Pencegahan Infeksi Aeromonas Hydrophilapada Benih Ikan Lele Clarias Spp. Yang Berumur 11 Hari Menggunakan Bawang Putih Allium Sativum Dan Meniran Phyllanthus Niruri. Departemen Budidaya Perairan, Fakultas Perikanan Dan IImu Kelautan, Institut Pertanian Bogor. Jurnal Akuakultur Indonesia. 12(1):94-104 